\begin{tabular}{|c|c|c|}
\hline 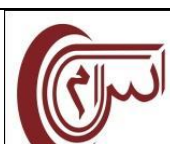 & $\begin{array}{c}\text { Klinikal Sains } 8(1)(2020) \\
\text { JURNAL ANALIS KESEHATAN } \\
\text { KLINIKAL SAINS }\end{array}$ & KLINIKALSAINS \\
\hline 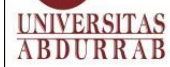 & http://jurnal.univrab.ac.id/index.php/klinikal & 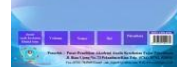 \\
\hline
\end{tabular}

\title{
PERBEDAAN KADAR GLUTATION PEROKSIDASE PADA PENDERITA TB DALAM MASA PENGOBATAN KURANG DARI 6 BULAN DAN LEBIH DARI 6 BULAN DI KOTA BENGKULU TAHUN 2019
}

\author{
Putri Widelia Welkriana* dan Tedy Febriyanto \\ Poltekkes Kemenkes Bengkulu \\ Jalan Indragiri Nomor 03 Padang Harapan Kota Bengkulu \\ *e-mail: putri_widelia2@yahoo.com
}

\begin{tabular}{l}
\hline Info Artikel \\
\hline \\
Sejarah Artikel: \\
Diterima : April 2020 \\
Disetujui : April 2020 \\
Dipublikasikan : Juni 2020
\end{tabular}

Keywords: Glutathione peroxidase, 6 months treatment, tuberculosis

\section{Abstrak}

Perubahan GSH mempunyai hubungan dengan kejadian TBC paru dan penyakit komplikasi yang terkait. Kadar glutation yang menurun pada penderita TBC paru diduga menyebabkan gangguan regulasi fungsi sel imun, dan menyebabkan kegagalan menangkal Reactive oxygen species/ROS. Pasien TBC paru mengalami penurunan dalam sel mononuklear darah perifer (PBMC) dan sel darah merah (RBC). Tujuan penelitian ini ialah menganalisis kadar glutation peroksidase pada penderita TB dalam masa pengobatan selama kurang dan lebih dari 6 bulan.

Metode yang digunakan pada penelitian ini bersifat observasional analitik dengan metode cross sectional. Variabel yang digunakan adalah variabel independen yaitu penderita TB dalam masa pengobatan kurang dan lebih dari 6 bulan dan variabel dependen yaitu kadar glutation peroksidase. Jumlah sampel penelitian yaitu 45 orang. Data dianalisis secara dengan menggunakan software statistic dan uji independent $t$. Hasil penelitian ini mempunyai hasil kadar glutation peroksidase pada penderita TBC dengan pengobatan kurang dari 6 bulan adalah 2,79 $\pm 1,27$ dan kadar glutation peroksidase pada penderita TBC dengan pengobatan lebih dari 6 bulan adalah 3,025 $\pm 2,19$ (nilai $\mathrm{p}=0,005$ ).

Kesimpulan, Tidak ada perbedaan nyata antara kadar glutation peroksidase antara penderita TBC dengan pengobatan kurang dari 6 bulan dan lebih dari 6 bulan.

Kata Kunci : Glutation peroksidase, Pengobatan 6 bulan, TBC

\section{Abstract}

Changes in GSH have a relationship with the incidence of pulmonary tuberculosis and related disease complications. Decreased glutathione levels in patients with pulmonary $T B$ are thought to cause impaired regulation of immune cell function, and cause failure to ward off Reactive oxygen species / ROS. Pulmonary TB patients experience a decrease in peripheral blood mononuclear cells (PBMC) and red blood cells $(R B C)$. This research to analyze the level of glutathione peroxidase in TB patients in the treatment period for less and more than 6 months. This Method research was analytic observational with cross sectional method. The variable used is an independent variable that is TB patients in the treatment period of less and more than 6 months and the dependent variable is the level of glutathione 


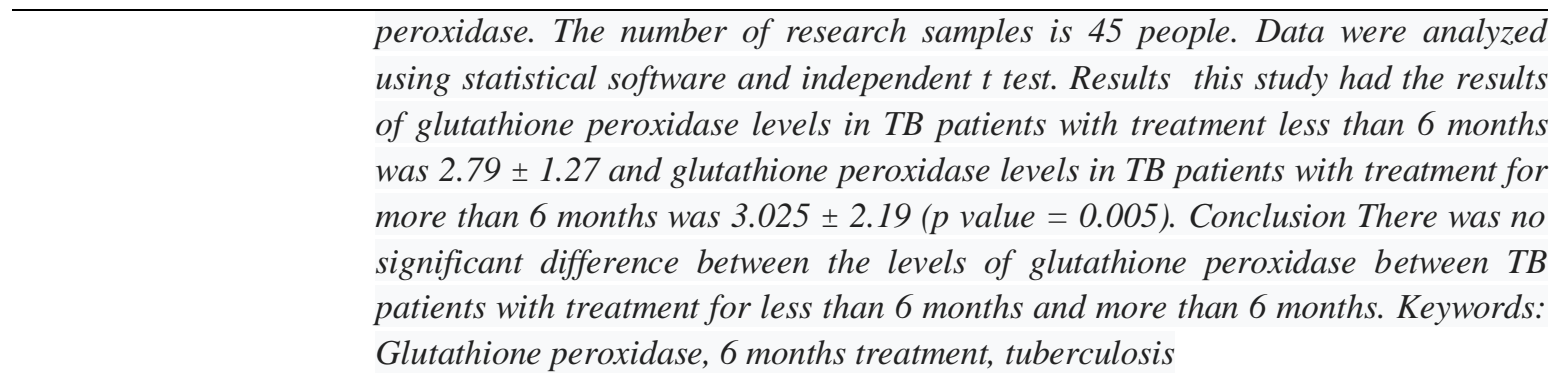

Keywords: Glutathione peroxidase, 6 months treatment, tuberculosis

(C) 2020 Universitas Abdurrab

Alamat korespondensi: Padang Harapan, Kota Bengkulu

ISSN 2338-4921

Alamat alamat alamat

E-mail: putri_widelia2@yahoo.com

\section{PENDAHULUAN}

Glutation ( $\gamma$-L-glutamil-L-cysteinyl-glisin) adalah 3 gugus peptida dengan kandungan glisin, asam glutamat, dan sistein. Asam-asam amino tersebut dihubungkan dengan ikatan gamma peptida. Ikatan gamma tersebut terdapat pada gugus amin sistein dan gugus karboksil glutamat. Sintesis glutation melalui 2 tahap yang masing-masing dikatalisis oleh enzim yang berbeda.Konsentrasi GSH pada hati dapat mencapai 5-10 mM. Sedangkan GSSG kurang dari 1\% GSH. GSH disimpan dalam 3 tempat utama pada sel eukariotik, yaitu hampir 90\% GSH seluler berada pada sitosol, $10 \%$ pada mitokondria dan sisanya berada pada retikulum endoplasma. Kadar glutation di dalam darah berada dalam rentangan 5-8 mM/L, dengan konsentrasi tertinggi di dalam hati, , juga terdapat pada lien, ginjal, paru, jantung, otak dan lambung. Kadar glutation dalam tubuh harus diperhatikan karena terganggunya sintesis dan metabolisme GSH akan mengakibatkan fungsi glutation terganggu dan mengakibatkan munculnya berbagai penyakit dalam tubuh seperti liver, aging, cystic fibrosis, Parkinson dll. Glutation berfungsi dalam status tiol redoks sel, pencegahan terhadap kerusakan oksidatif, detoxifikasi endogen dan eksogen logam reaktif, penyimpanan dan transportasi sistein, serta untuk protein dan sintesis DNA, regulasi siklus sel serta diferensiasi sel. Ketidakseimbangan homeostasis GSH menunjukkan perkembangan sejumlah penyakit pada manusia. Penelitian terbaru telah menemukan peran GSH dalam mengatur ekspresi gen, apoptosis, dan transportasi membran molekul endogen dan eksogen. Selain itu, glutation juga memiliki beberapa kegunaan antara lain detoksikasi, antioksidan dan pemeliharaan status tiol dan modulasi proliferasi sel. Glutation juga sebagai agen pertahanan tubuh terhadap racun xenobiotik, yang berupa obatobatan, polutan dan karsinogen. Sebagai antioksidan, glutation berperan dalam proteksi sel 
akibat efek dari kelebihan zat oksidan. Aktivtitas enzim yang terlibat dalam metabolisme GSH dikendalikan saat tingkat transkripsi, translasi, dan pascatranslasi. Beberapa sistem sinyal seluler diketahui terlibat dengan aktivitas ini. Biosintesis GSH dilakukan oleh enzim. Dalam memanipulasi biosintesis GSH, dilakukan oleh GCLC, dan selanjutnya detoksifikasi tahap II melibatkan peran enzim Glutation-S transferase (GSTs).

Pengaturan enzim-enzim ini terutama di tingkat ekspresi dan beberapa mekanisme yang terlibat. Enzim-enzim yang mensintesis glutation diekspresikan secara genetik oleh Glutamate Cystein Ligase (GCL). Enzim glutamate cystein ligase terdiri atas sub unit katalitik yang disandi oleh gen glutamate Cystein Ligase Catalitic (GCLC) dan sub unit modulator yang disandi oleh gen glutamate Cystein Ligase Modifier (GCLM). Perubahan aktivitas GCL mempengaruhi regulasi di berbagai tahapan dan akan mempengaruhi ekspresi GCL sub unit katalitik atau keduanya GCLC dan GCLM. Glutation (GSH) merupakan komponen kunci dalam regulasi homeostasis reduksi-oksidasi. Perubahan kadar GSH diduga menyebabkan kejadian penyakit antara lain TB paru, kardiovaskular, diabetes mellitus, cystic fibrosis, neurodegenerative, AIDS, kanker, penuaan, gangguan hati, dan penyakit komplikasi yang terkait. Penurunan kadar glutation pada penderita TB paru diduga menyebabkan gangguan regulasi fungsi sel imun, dan menyebabkan kegagalan menangkal Reactive Oxygen Species/ROS (Venketaraman et al., 2005). Pasien TB paru dengan infeksi HIV mengalami penurunan kadar GSH secara signifikan dalam sel mononuklear darah perifer (PBMC) dan sel darah merah (RBC) (Venketaraman et al., 2006; Venketaraman et al., 2008. Perbedaan ekspresi dan aktivitas enzim GCL kemungkinan karena pengaruh variasi dalam urutan asam-asam amino yang berhubungan dengan timbulnya suatu penyakit seperti : gangguan fungsi paru (Siedinski et al., 2008; Breton et al., 2010), infark miokard (Koide et al., 2003), cystic fibrosis (McKone et al., 2006) disfungsi endotel (Nakamura et al., 2002; Nakamura et al., 2003; Zuo et al., 2007), HIV/AIDS (Wang et al., 2012), kanker (Walsh et al., 2001), COPD (Hu et al., 2006; Liu et al., 2007), penyakit perlemakan hati (Oliviera et al., 2010; Hashemi et al., 2011 diabetes (Bekris et al., 2007; Vieira et al., 2011)), Polimorfisme mengakibatkan ekpresi dan aktivitas enzim GCL secara signifikan berkurang dan fenotip menunjukkan keparahan penyakit. Rendahnya kadar GSH pada pasien TB paru berhubungan dengan adanya variasi gen glutamate cysteine ligase (GCL) pada individu penderita (Yuniastuti dan Dewi, 2012). Di dunia, Tuberculosis menyebabkan kematian sampai 93\%. Indonesia berada pada rangking kelima negara dengan beban TB tertinggi di dunia (WHO,2014). Estimasi prevalensi berjumlah 430.000 kasus per tahun. Jumlah kematian akibat TB diperkirakan 61000 kematian per tahunnya. Pada tahun 2017 Bengkulu mempunyai angka kejadian sebesar 55.560 dan kematian sebanyak 4.1 persen. 


\section{METODE}

Penelitian ini bersifat observasional analitik dengan metode cross sectional. Variabel yang digunakan dalam penelitian ini adalah variabel independen yaitu penderita TB dalam masa pengobatan kurang dan lebih dari 6 bulan dan variabel dependen yaitu kadar glutation peroksidase.Populasi penelitian ini adalah keseluruhan penduduk yang penderita Tuberkulosis dengan masa pengobatan kurang dan lebih dari 6 bulan yang bertempat tinggal di Kota Bengkulu.Sampel dalam penelitian ini berdasarkan perhitungan rumus dari besarnya populasi sebanyak 37 orang. Berdasarkan perhitungan dengan rumus tersebut, maka diperoleh jumlah sampel penelitian yaitu 45 orang. Kriteria inklusi yang dipenuhi antara lain : (1) Penderita Tuberkulosis (2) Dalam masa pengobatan kurang dan lebih dari 6 bulan. Sampel penelitian diambil dengan metode Random Sampling.Penelitian akan dilakukan di Kota Bengkulu, sedangkan tempat pemeriksaan kadar glutation peroksidase akan dilakukan di laboratorium terpadu Poltekkes Kemenkes Bengkulu.Penelitian akan dilakukan pada bulan FebruariDesember 2019.

Sampel darah diambil sebanyak $3 \mathrm{cc}$. Selanjutnya sampel dimasukkan ke dalam tabung mikrosentrifus yang berisi EDTA. Selanjutnya plasma darah yang terpisah lalu dimasukkan ke dalam tip sampel. Tabung sampel+EDTA disentrifugasi dengan kecepatan $3000 \mathrm{rpm}$ selama 10 menit. Lalu dilakukan pengenceran Diluent Solution sebanyak 5X untuk mendapatkan $10 \mathrm{~mL}$ diluent sol 1x sebanyak $2 \mathrm{~mL}$ Diluent sol. Lalu ditambahkan $8 \mathrm{~mL}$ Aquades. Pengenceran dilakukan pada 500bp, 302bp, 198bp, 113bp tabung eppendorf. Tabung diisi $5 \mu \mathrm{L}$ Sampel dan ditambahkan $495 \mu \mathrm{L}$ Diluent $1 \mathrm{X}$ berisi 1/100 dilution kemudian disentrifugasi. Pembuatan larutan standar melalui tahapan : Siapkan 8 tabung eppendorf yang berisi Standard 7 berisi 8 $\mu \mathrm{L}$ Human Pre-Calibrator dan ditambahkan $677 \mu \mathrm{L}$ Diluent $1 \mathrm{X}$ sentrifugasi. Selanjutnya Standard 6 berisi $300 \mu \mathrm{L}$ standard 7 ditambahkan $300 \mu \mathrm{L}$ Diluent $1 \mathrm{X}$ sentrifugasi. Lalu Standard 5 berisi $300 \mu \mathrm{L}$ standard 6 ditambahkan $300 \mu \mathrm{L}$ Diluent $1 \mathrm{X}$ sentrifugasi. Standard 4 berisi $300 \mu \mathrm{L}$ standard 5 dan $300 \mu \mathrm{L}$ Diluent $1 \mathrm{X}$ sentrifugasi. Standard 3 berisi $300 \mu \mathrm{L}$ standard 6 dan $300 \mu \mathrm{L}$ Diluent $1 \mathrm{X}$ sentrifugasi. Standard 2 berisi $300 \mu \mathrm{L}$ standard 3 dan $300 \mu \mathrm{L}$ Diluent $1 \mathrm{X}$ sentrifugasi. Standard 1berisi $300 \mu \mathrm{L}$ standard 2 dan $300 \mu \mathrm{L}$ Diluent $1 \mathrm{X}$ sentrifugasi. Standard 0 berisi $600 \mu$ L Diluent $1 X$.

Data yang diambil pada penelitian ini menggunakan data primer yang diperoleh berdasarkan hasil pemeriksaan kadar glutation peroksidase. Data dikumpulkan oleh peneliti dari setiap responden yang berada di Kota Bengkulu.Data yang telah diperoleh akan dianalisis secara univariat dengan menggunakan software statistik. Analisis Univariat dilakukan secara deskriptif dengan distribusi frekuensi dari variabel.Analisis bivariat dilakukan untuk menguji hubungan antara variabel independen terhadap variabel dependen dengan menggunakan uji independent $t$. 


\section{HASIL DAN PEMBAHASAN}

Penelitian ini dilaksanakan pada bulan Juni-Oktober 2019. Subjek dalam penelitian ini adalah penderita TBC dalam masa pengobatan kurang dari 6 bulan dan lebih dariu 6 bulan. Data yang memenuhi kriteria restriksi berjumlah 37 orang. Karakteristik berdasarkan usi didapatkan rerata seluruh subjek penelitian $( \pm \mathrm{SD})$ adalah $47,75 \pm 8,69$ tahun, usia termuda adalah 37 tahun, sedangkan usia tertua adalah 56 tahun. Karakteristik Subjek penelitian dapat dilihat pada Tabel 1. Uji normalitas bisa dilihat pada Tabel 2. Selanjutnya dilakukan uji t-test dilihat pada Tabel 3.

Tabel 1. Distribusi Subjek Penelitian

\begin{tabular}{lccc}
\hline \multicolumn{1}{c}{ Karakteristik } & $\begin{array}{c}\text { Kelompok TBC dalam } \\
\text { pengobatan }\end{array}$ & N $(\%)$ & Rerata \\
\hline Jenis Kelamin & $<6$ bulan & $10(27,03 \%)$ & \\
Pria & $\geq 6$ bulan & $7(18,92 \%)$ & \\
Wanita & $<6$ bulan & $11(29,73 \%)$ & \\
& $\geq 6$ bulan & $9(24,32 \%)$ & $42,75 \pm 5,54$ \\
Usia & $<6$ bulan dan $\geq 6$ bulan & & \\
$<54$ tahun & $<6$ bulan & $16(43,24 \%)$ & \\
$\geq 54$ tahun & $\geq 6$ bulan & $18(48,64 \%)$ & \\
& $<6$ bulan & $2(5,4 \%)$ & \\
Kadar Glutation & $\geq 6$ bulan & $1(2,7 \%)$ & $2,79 \pm 1,27$ \\
Peroksidase & $<6$ bulan & & $3,025 \pm 2,19$ \\
\hline
\end{tabular}

Sumber: Data Sekunder, 2019

Tabel 2. Uji Normalitas

\begin{tabular}{lccc}
\hline Variabel Terikat & Variabel Bebas & \multicolumn{2}{c}{ Shapiro-Wilk } \\
\cline { 3 - 4 } & & Frekuensi & $\mathbf{p}$ \\
\hline Kadar glutation peroksidase & $\mathrm{TBC}<6$ bulan & 21 & 0,05 \\
& $\mathrm{TBC} \geq 6$ bulan & 16 & 0,05 \\
\hline
\end{tabular}

Sumber: Data Primer, 2019

Tabel 3. Uji T Independen

\begin{tabular}{lccc}
\hline Gx plasma $(\mathbf{n m o l} / \mathbf{m e n i t} / \mathbf{m L})$ & $\mathbf{n}$ & Rerata $\pm \mathbf{s b}$ & $\mathbf{p}$ \\
\hline $\mathrm{TBC}<6$ bulan & 21 & $2,79 \pm 1,27$ & 0,005 \\
$\mathrm{TBC} \geq 6$ bulan & 16 & $3,025 \pm 2,19$ & \\
\hline
\end{tabular}

Sumber: Data primer, 2019

\section{PEMBAHASAN}

Berdasarkan hasil penelitian peningkatan kadar glutation peroksidase darah paling banyak terjadi pada kelompok umur kurang dari 54 tahun dengan frekuensi 34 sampel (91\%). Hasil 
penelitian tersebut sesuai dengan data Kemenkes (2016) yang menyatakan bahwa penderita TBC dengan umur antara 25-34 tahun yang paling tinggi. Dalam penelitian Yuniastuti (2013) menyatakan bahwa kelompok yang memiliki peningkatan kadar glutation peroksidase adalah kelompok umur kurang dari 54 tahun dengan sampel sebesar 113 sampel (87\%). Hal tersebut membuktikan bahwa infeksi Mycobacterium tuberculosis panyak ditemukan pada rentang umur tersebut. Hasil ini disebabkan oleh adanya interaksi dari percikan dahak antara penderita TBC dan lingkungan sekitarnya. Hasil penelitian peningkatan kadar glutation peroksidase dengan masa pengobatan lebih dari dan sama dengan dari 6 bulan sebanyak 16 sampel $(43,24 \%)$ sebesar $3,025 \pm 2,19$. Pada kelompok TBC dengan masa pengobatan kurang dari 6 bulan sebanyak 21 sampel $(56,75 \%)$ mempunyai kadar glutation peroksidase sebesar 2,79 $\pm 1,27$. Hasil ini serupa dengan penelitian yang dilakukan Yuniastuti (2013) setelah pemberian OAT kadar glutation mengalami peningkatan sebesar 2,2\% meskipun masih lebih rendah dari kadar glutation normal. Peningkatan kadar glutation peroksidasepada kelompok pengobatan lebih dari 6 bulan ini dihubungkan oleh pengaruh glutaion peroksidase pada pasien tuberkulosis paru (TB paru), rendahnya antioksidan menyebabkan kerusakan jaringan. Salah satu antioksidan tubuh adalah glutation. Rendahnya glutation berhubungan dengan gangguan sistem imun, sehingga menyebabkan keparahan penyakit pada pasien TB paru.

Berdasarkan hasil karakteristik subjek penelitian pada tabel 1 menunjukkan bahwa penderita TBC dengan pengobatan kurang dan lebih dari 6 bulan lebih banyak yang berjenis kelamin wanita, yaitu dengan total sampel 20 orang (54,06\%), dibandingkan dengan yang berjenis kelamin pria, dengan total sampel 17orang $(45,94 \%)$. Uji normalitas dilakukan untuk mengetahui apakah data terdistribusi normal atau tidak, jika data terdistribusi dengan normal maka akan digunakanuji $\mathrm{T}$ tidak berpasangan sedangkan jika data terdistribusi tidak normal maka akan digunakan uji Mann Whitney. Jumlah sampel adalah 37 subjek, maka akan digunakan uji normalitas Shapiro-Wilk. Sebaran data dikatakan normal, apabila nilai p pada uji normalitas Shapiro-Wilk lebih dari 0,05. Pada tabel 2 menunjukkan nilai p variabel kadar glutation peroksidase. Dari tabel uji normalitas Shapiro-Wilk didapatkan hasil bahwa distribusi data kadar glutation peroksidase pada kelompok penderita TBC dengan pengobatan kurang dari 6 bulan yaitu p>0,05, yang berarti data terdistribusi dengan normal. Hasil ini sama dengan distribusi data kadar glutation peroksidase pada kelompok penderita TBC dengan pengobatan lebih dari 6 bulan yaitu p>0,05, yang berarti data juga terdistribusi dengan normal, jadi untuk uji analisisnya menggunakan uji Independent-T (Dahlan, 2010).

Uji independent $\mathrm{T}$ dilakukan sesuai dengan hasiluji normalitas. Tabel 3 diatas menunjukkan hasiluji Independent $\mathrm{T}$ dari kadar glutation peroksidase dan didapatkan nilai $\mathrm{p}=0,005$, artinya terdapat perbedaan yang belum signifikan antara rerata kadar glutation 
peroksidase pada penderita TBC dalam masa pengobatan kurang dan lebih dari 6 bulan, karena nilai $\mathrm{p}=0,05$, dimana kadar glutation peroksidase pada penderita $\mathrm{TBC}$ denga masa pengobatan lebih dari 6 bulan lebih tinggi daripada kadar glutation peroksidase penderita TBC dengan pengobatan kurang dari 6 bulan, dimana rerata kadar glutation peroksidasependerita TBC dengan masa pengobatan kurang dari 6 bulan adalah 2,79 $\pm 1,27$ sedangkan pasien TBC dengan masa pengobatan lebih dari 6 bulan adalah 3,025 $\pm 2,19$.

Perubahan kadar glutation menyebabkan teragnggunya sintesis dan metabolisme GSH dan menyebabkan berbagai penyakit seperti cyctic fibrosis, liver, Parkinson, dll.Glutation berfungsi dalam kestabilan status tiol redoks sel, pencagahan terhadap kerusakan oksidatif, detoxifikasi endogen dan eksogen logam reaktif, penyimpanan dan transportasi sistein, serta sintesis DNA, regulasi siklus sel dan diferensiasi sel. Glutation peroksidase merupakan suatu antioksidan endogen yang berperan dalam mencegah pembentukan senyawa radikal bebas yang telah terbentuk menjadi molekul reaktif. Enzim glutation peroksidase berperan dalam mengubah $\mathrm{H}_{2} \mathrm{O}_{2}$ yang dihasilkan oleh superoksida dismutase menjadi bentuk air (Sugianto 2011). Hasil penelitian rerata aktivitas enzim glutation peroksidase dalam tubuh adalah 74,2096 U/g, sedangkan umumnya aktivitas enzim glutation peroksidase dalam tubuh adalah $31 \mathrm{U} / \mathrm{g}$.

Sejumlah penyakit pada manusia disebabkan oleh ketidakstabilan homeostatis GSH. Penelitian terakhir menunjukkan GSH dalam mengatur ekspresi gen, apoptosis, dan transportasi membran molekul endogen dan eksogen. Glutation juga memiliki beberapa fungsi antara lain detoksikasi, antioksidan dan modulasi proliferasi sel. Glutation berperan dalam proteksi sel akibat efek dari kelebihan zat oksidan. Metabolisme GSH dikendalikan pada tingkat transkripsi, translasi, dan pascatranslasi saat mnghasilkan aktivitas enzimdalam mencegah kejadian penyakit (Yuniastuti dan Dewi, 2012).

Perubahan kadar GSH diduga sebagai penyebab kejadian penyakit antara lain TB paru, kardiovaskular, AIDS, neurodegenerative, kanker, penuaan, diabetes mellitus, cystic fibrosis, gangguan hati, dan penyakit komplikasi yang terkait. Kadar glutation yang rendah pada penderita TB paru diduga menyebabkan gangguan regulasi fungsi sel imun, dan menyebabkan kegagalan menangkal Reactive oxygen species/ROS (Venketaraman et al., 2005). Selain itu, Adanya variasi gen glutamate cysteine ligase (GCL) pada individu penderita menyebabkan rendahnya aktivitas ennzim SGH (Yuniastuti dan Dewi, 2012).

GSH ekstraseluler mengalami penurunan kadar karena enzim $\gamma$-glutamyl transpeptidase (juga disebut $\gamma$-glutamil transferase, atau $\gamma$-GT) mengalami gangguan. Enzim $\gamma$-glutamil transpeptidase merupakan satu-satunya enzim yang dapat memulai katabolisme GSH, glutation S-konjugasi, dan glutathione-kompleks dalam kondisi fisiologis. Dalam empedu, GSH, GSSG,dan GS konjugat mengalami degradasi oleh ectoenzymes katabolik $\gamma$-glutamil 
transpeptidase dan dipeptidase. GSH memasuki pembuluh darah ke dalam ruang ekstraselular. Selanjutnya $\gamma$-glutamil transpeptidase menghilangkan gugus glutamil dari GSH. Senyawa ini merupakan substrat untuk dipeptidase. Dipeptidase menghidrolisis ikatan peptida antara sistein dan glisin (Handayani, 2002).

Aktivitas $\gamma$-ECS dan sistein menghasilkan produksi glutation diregulasi melalui beberapa level. Hal ini ditunjukkan dengan adanya overekspresi oleh kedua enzim tersebut. Aktivitas enzim ini tergantung adanya ketersediaan glisin dan ATP. Adanya paparan logam berat, GSH diperlukan sebagai antioksidan dan percepatan sintesis. Hal ini diduga konsentrasi glutation akan mengalami penurunan. Saat kondisi stres yang berlainan yang disebabkan komponen oksidatif yang kuatmenyebabkan peningkatan sintesis akan terjadi dengan terakumulasinya glutation. Respon ini ditingkatkan dengan tujuan untuk mengimbangi ketidakstabilan redoks. Redoks yang tidak stabil disebabkan oleh adanya peningkatan GSSG. Studi menggunakan enzim $\gamma$-ECS dari bakteri E. coli yang diberikan pada kloroplas tembakau, menunjukkan peningkatan glutation pada daun menjadi 4 kali lipat. Pengaruh $\gamma$-ECS yang berlebih dalam tembakau menyebabkan pembentukan lesi dan akumulasi GSSG tinggi (Handayani, 2002). Gordon (1993) menyatakan bahwa pada konsentrasi tinggi, aktivitas antioksidan sering lenyap bahkan antioksidan tersebut menjadi prooksidan.Keterbatasan dalam penelitian ini adalah pada saat pengambilan dan proses preparasi sampel terjadi kerusakan yang menyebabkan sampel tidak dapat dianalisis sehingga dalam penelitian selanjutnya perlu penambahan sampel dan berhati-hati saat membawa sampel menuju laboratorium untuk dipreparasi.

\section{SIMPULAN}

Berdasarkan penelitian dan pembahasan tentang perbedaan kadar glutation peroksidase pada penderita TBC dalam masa pengobatan kurang dari 6 bulan dan lebih dari dari 6 bulan dapat disimpulkan :

a. Kadar glutation peroksidase pada penderita TBC dalam masa pengobatan kurang dari 6 bulan adalah $2,79 \pm 1,27$.

b. Kadar glutation peroksidase pada penderita TBC dalam masa pengobatan lebih dari 6 bulan adalah $3,025 \pm 2,19$.

c. Tidak ada perbedaan secara nyata antara kadar glutation peroksidase pada penderita TBC dengan masa pengobatan kurang dari 6 bulan dan lebih dari 6 bulan.

\section{SARAN}

Berdasarkan penelitian dan pembahasan peneliti ingin memberi saran kepada semua pihak yang terkait, antara lain : 
1. Bagi Akademik

Sebagai sumber informasi dan referensi bacaan bagi mahasiswa Jurusan Analis Kesehatan Poltekkes Kemenkes Bengkulu tentang perbedaan kadar glutation peroksidase antara penderita TBC dalam masa pengobatan kurang dari 6 bulan dan lebih dari 6 bulan.

2. Bagi Peneliti Lain

Diharapkanselanjutnya melakukan uji polimorfisme gen yang menyebabkan perbedaan kadar glutation pada penderita TBC dalam masa pengobatan kurang dari 6 bulan dan lebih dari 6 bulan.

3. Masyarakat dan petugas Kesehatan

Penelitian ini dapat melengkapi informasi tentang pemeriksaan laboratorium pada pasien TB khususnya, sebagai metode deteksi cekaman oksidatif yang cepat, tepat, mudah dilakukan dengan sensitivitas dan spesifisitas yang tinggi.

\section{UCAPAN TERIMA KASIH}

Ucapan terima kasih kepada pahak terkait yang telah membantu dan bekerjasama demi kelancaran penelitian ini. Penelitian ini terselenggara karena adanya dana yang diberikan oleh Poltekkes Kemenkes Bengkulu dan kolaborasi dengan Tedy Febriyanto,M.Bmd, serta kerja sama dengan Dinas Kesehatan Provinsi Bengkulu selama tahun 2019.

\section{DAFTAR PUSTAKA}

Abbas, A.K., Lichtman, A, and Pober, J.S. 2011. Cellular and Molecular Immunology. Second ed. WB Saunders Co : Philadelphia. p: 327.

Ahi, R.S., Deepak, A., Singh, R. 2010. Oxidative Stress and Ascorbic Acid Levels in Cavitary Pulmonary Tuberculosis. Journal of Clinical And Diagnostic Research 4:3437-3441.

Akiibino, M.O., Ogunyemi, E.O., and Shoyebo, E.O. 2011. Levels of Oxidative Metabolites, Antioxidants and Neopterin in Nigerian Pulmonary Tuberculosis Patients. Eur. J. Gen. Med. 8(3): 213-218. 2011-12-24.

Akerboom, T.P., Bilizer, M.M., Sies, H. 1982. The relationship of biliary GSSG efflux and intracellular GSSG content in perfused rat liver. J Biol Chem 257:4248-4252. 65.

Antczak, A., Montuschi, P., Kharitonov, S.A., Gorski, P., Barnes, P.J. 2002. Increased exhaled cysteinyl-leukotrienes and 8-isoprostane in aspirininduced asthma. Am. J. Respir. Crit. Care Med. 166:301-306.

Baraldi, E., Ghiro, L., Piovan, V. 2003a. Increased exhaled 8-isoprostane in childhood asthma. Chest 124:25-31. 
Baraldi, E., Carraro, S., Alinovi, R., Pesci, A., Ghiro, L., Bodini, A., Piacentini, G., Zacchello, F., Zanconato, S. 2003b. Cysteinyl leukotrienes and 8- isoprostane in exhaled breath condensate of children with asthma exacerbation. Thorax 58:505-509.

Barmawi. 2004. Tuberkulosis : Ancaman Kegawatan Dunia Aspek Imunologi dan Terapi. Pidato Pengukuhan Jabatan Guru Besar pada Fakultas Kedokteran Universitas Gadjah Mada. Yogyakarta.

Basaraba, R.J. 2008. Experimental tuberculosis: the role of comparative pathology in the discovery of improved tuberculosis treatment strategies. Tuberculosis (Edinb) 88 Suppl 1: S35-47

Bekris, L.M., Viernes, H.M., Farin, F.M., Maier, L.A., Kavanagh, T.J., Takaro, T.K. 2006. Chronic beryllium disease and glutathione biosynthesis genes. J. Occup. Environ. Med;48(6):599-606

Benndrof, R.A., Schwehelm, Z., Gnann, A., Taheri, R., Komli et al. 2008. Isoprostane Inhibit Vascular Endothelial Growth Factor-Induced Endothelial Cell Migration, Tube Formation, and Cardiac Vessel Spraving in vitro, as well as Angiogenesis in vibo via Activation of The Tjromoboxane A(2) Receptor; A potential link between oxidative stress and impaired angiogenesis. Circ. Resp. 103(9):1037-1046.

Biernacki, W.A., Kharitonov, S.A., Barnes, P.J. 2003. Increased leukotriene B4 and 8isoprostane in exhaled breath condensate of patients with exacerbations of COPD. Thorax 58, 294-298 Biolo, G., Antonione, R., De Cicco M. 2007. Glutathione metabolism in sepsis. Crit Care Med. 35(9 Suppl):S591-S595

Biswas, S., Rahman, I. 2008. Environmental toxicity, redox signaling and lung inflammation: the role of glutathione. Mol. Aspects Med.

Bulatovic, V.M., Wengenack, N.L., Uhl, R.J., Hall, L., Roberts, G.D., Cockerill, F.R., Rusnak, F. (2002). Oxidative Stress Increases Susceptibility of Mycobacterium Tuberculosis to Isoniazid. Antimicrobial Agents Chemoteraphy. 46:2765-2771.

Carpagnano, G.E., Kharitonov, S.A., Resta, O., Foschino-Barbaro, M.P., Gramiccioni, E., Barnes, P.J. 2002. Increased 8-Isoprostane and Interleukin-6 in Breath Condensate of Obstructive Sleep Apnea Patients. Chest 122, 1162-1167.

Carpenter, C.T., Price, P.V., Christman, B.W. 1998. Exhaled breath condensate isoprostanes are elevated in patients with acute lung injury or ARDS. Chest 114, 1653-1659.

Chen, Y., Shertzer, H.G., Schneider, S.N., Nebert, D.W., Dalton, T.P. 2005. Glutamate cysteine ligase catalysis: dependence on ATP and modifier subunit for regulation of tissue glutathione levels. J. Biol. Chem 280(40):33766-33774.

Chew, B.P and Park, J.S. 2004. Caretenoid Action on The Immune Response. J. Nutr 134;257S$261 \mathrm{~S}$

Chowdhury, A., Santra, A., Kundu, S., Mukherjee, A., Pandit, A., Chauduri, S, and Dhali, G.K. 2001. Induction of Oxidative Stress in Antitubercular druginduced hepatotoxicity. Indian J. Gastroenteral. 20(3): 97-100. 
Connell, N.D and Venketaraman. V. 2009. Control of Mycobacterium tuberculosis infection by Glutathione Recent Patients on Anti-Infective. Drug Discovery 4;214-226.

Cracowski, J.L., Cracoski, C., Bessard, G., Pepin, J.L., Bessard, J., Scwebel, C., StankeLabesque, F., Pison, C. 2001. Increased Lipid Peroxidation in Patients with Pulmonary Hypertension. Am. J. respire. Crit Care Med. 164:1038-1042.

Dahlan, M.S. 2011. Statistik untuk Kedokteran dan Kesehatan : Deskriptif, Bivariat, dan Multivariat dilengkapi aplikasi dengan menggunakan SPSS. Salemba Medika : Jakarta.

Dasgupta, A., Das, S., Sarkar, P.K. 2007. Thyroid hormone promotes glutathione synthesis in astrocytes by up regulation of glutamate cysteine ligase through differential stimulation of its catalytic and modulator subunit mRNAs. Free Radic. Biol. Med 42(5):617-626.

Dayaram, Y.K., Talaue, M.T., Connell, N.D., Venketaraman, V. 2006. Characterization of a glutathione metabolic mutant of Mycobacterium tuberculosis and its resistance to glutathione and Nitrosoglutathione. J Bacteriology 188: 1364-72

Deneke, S.M., Fanburg, B.L.1989. Regulation of cellular glutathione. Am J Physiol 257(4 Pt 1): L163-173. DeLeve, L., Kaplowitz, N. 1990. Importance and regulation of hepatic GSH. Sem Liver Dis 10:251-266.

Departemen Kesehatan (2008). Pedoman Nasional Penanggulangan Tuberkulosis. Departemen Kesehatan Republik Indonesia: Jakarta.

Dröge, W. 2002. Free Radicals in The Physiological Control of Cell Function. Physicol Rev. 82: 47-95. Am. J. Respir Crot. Care med. 160:1947-1951.

Ehrt, S., and Schnappinger, D. 2009. Mycobacterial survival strategies in the phagosome: defence against host stresses. Cell. Microbiol. 11, 1170- 1178.

Erlina, B. 2010. Tuberkulosis Multi Drug Resistance (TB-MDR). Majalah Kedokteran Indonesia 60(12): 535-536.

Franklin, C.C., Rosenfled-Franklin, M.E., White, C., Kavanagh, T.J., Fausto, N. 2003. TGFß1induced suppression of glutathione antioxidant defenses in hepatocytes: caspasedependent posttranslational and caspaseindependent transcriptional regulatory mechanisms. FASEB J. 200310.1096/fj.02-0867fje.

Franklin, C.C., Backos, D.S, et al .2008. Functional roles and regulation of the catalytic and modifier subunits of glutamate cysteine ligase. Mol. Aspects Med.

Franklin, C.C., Backos, D.S., Mohar, I., White, C.C., Forman, H.J., Kavanagh, T.J. 2009. Structure, function, and post-translational regulation of the catalytic and modifier subunits of glutamate cysteine ligase. Mol Aspects Med. 30:86-98.

Garcia-Ruiz, C., Fernández-Checa, J.C. 2006. Mitochondrial glutathione: hepatocellular survival-death switch. J Gastroenterol Hepatol 21:S3-6.

Garcia-Ruiz, C., Fernández-Checa, J.C. 2007. Redox regulation of hepatocyte apoptosis. $J$ Gastroenterol Hepatol 22:S38-42. Garg, S., Vitvitsky, V., 
Gendelman, H.E., Banerjee, R. 2006 Monocyte differentiation, activation, and mycobacterial killing are linked to transsulfuration-dependent redox metabolism. J Biol Chem. 281(50): 38712-38720

Ghezzi, P., Simplicio, P. 2007. Glutathionylation pathways in drug response. Curr Opin Pharmacol. 7(4):398-403.

Ghezzi, P. 2005a. Oxidoreduction of protein thiols in redox regulation. Biochem Soc Trans. 33(Pt 6):1378-1381.

Ghezzi, P. 2005b. Regulation of protein function by glutathionylation. Free Radic Res. 39(6):573-580.

Ghezzi, P. 2011. Role of Glutathione in Immunity and Inflmation in The Lung. International Journal of General Medicine 4:105-113.

Griffith, O.W. 1999. Biologic and pharmacologic regulation of mammalian glutathione synthesis. Free Radic ATTN: Biol Med 9-10: 922-935.

Griffith, O.W., Mulcahy, R.T. 1999. The enzymes of glutathione synthesis: $\gamma$ glutamylcysteine synthetase. Adv. Enzymol. Relat. Areas Mol. Biol 73:209-267.

Guerra, C., Devin, M., Andrea, s., Steven, K., Meshare, F., Dennis, G., Michelle, T., Frederick, G., Fadi, T.K and Venketaraman, V. 2011. Glutathione and Adaptive Immune Response Against Mycobacterium tuberculosis Infection in Healthy and HIV Infected Individual. PLosOne 6(12):e28378.

Handayani, S..2002. Respon Imunitas Seluler Pada Infeksi Tuberkulosis Paru. Cermin Dunia Kedokteran 137:34-37.

Hashmi, M.A., Bilal, A., Syed, I.A.S and Muhammad, I.U.K. 2012. Antioxidant Capacity and Lipid Peroxidation Product in Pulmonary Tuberculosis. Al Ameen J Med Sci 5 (3 ):313319

Hashimoto, K., Takasaki, W., Yamoto, T., Manabe, S., Sato, I., Tsuda, S. 2008. Effect of glutathione (GSH) depletion on DNA damage and blood chemistry in aged and young rats. J Toxicol Sci 33:421-9.

Heisterkamp, N., Jackson, A.A., Gibson, N.R., Lu, Y., Jahoor, F. 2004. Synthesis of erythrocyte glutathione in healthy adults consuming the safe amount of dietary protein. Am J Clin Nutr. 80(1):101-107

Johnkennedy, N., Anyadoh, S.O., Nwosu, N., Emmanuel, C. 2011. The antioxidant status and lipid peroxidation product of newly diagnosed and 6 weeks follow-up patients with pulmonary tuberculosis in Owerri, Imo state, Nigeria. Asian Pacific Journal of Tropical Disease:292-294.

Kaplowitz, N., Aw, T.Y., Ookhtens, M. 1985. The regulation of hepatic GSH. Ann Rev Pharm Toxicol 25:714-744.

Kaufmann, S.H.E. 2004. New Issues in Tuberculosis. Annals of The Rheumatic Diseases 63:5056. 
Kaur, K., Jai, K., Gurdeep, K.B, and Rajinderjit, S.A. 2005. Oxidants Stress And Antioxidant in Pulmonary Tuberculosis. diakses tanggal 30 Juli 2011.

Kumar, A., Aisha, F., Ioni, G., Vikram, S., Mary, H and Adrie, J.C.S. 2011. Redox Homeostasis in Mycobacteria : The Key to Tuberculosis Control ? Expert Review in Molecular Medicine 13:39-49.

Kwiatkowska, S., Piasecka, G., Zieba, M., Piotmoski, W., Nowak, D. 1999. Increased Serum Concentration of Conjugated malondialdehyda in patients with pulmonary tuberculosis. Respir Med. 93:272-276.

Lamsal, M., Narayan, G., Narendra, B., Bishamber, D.T., Shymal, K.B. and Nirmal, B. 2007. Evaluation of Lipid Peroxidation Product, Nitrite And Antioxidant Levels In Newly Diagnosed And Two Months Follow-Up Patients With Pulmonary Tuberculosis. Southeast Asian J Trop Med Public Health 38(4):695-703

Lushchak, V.I. 2012. Glutathione Homesotasis and Functional : Potential Targets for Medical Intervention. Journal of Amino Acids. DOI:10.1155/2012/736837.

Am Malmezat T, Breuille D, Capitan P, Mirand PP, Obled C. 2000. Glutathione turnover is increased during the acute phase of sepsis in rats. J Nutr. 130(5):1239-1246.

Meister A. 1992. Biosynthesis and function of glutathione, an essential biofactor. J. Nutrit. Sci. Vitaminol. Spec No: 1-6

Mohod, K., Archana, D, and Smith, K. 2011. Status of Oxidants and Antioxidants in Pulmonary Tuberculosis With Varying Bacillary Load. Journal of Experimental Science. 2(6):35-37.

Morrow JD, Roberts LJ II. 1999. Mass spectrometric quantification of F2- isoprostanes in biological fluids and tissues as measure of oxidant stress. Methods Enzymol 300:3-12.

Morrow, J.D and Roberts, LJ II. 2002. The Isoprostane Their Roles as an Index of Oxidant Stress Status in Human Pulmonary Disease. American Journal of Respiratory and Critical Care Medicine 166.

Munir SM, Arifin N dan Dianiati KS 2010. Pengamatan Pasien Tuberkulosis Paru dengan Multidrug Resistant (TB-MDR) di Poliklinik Paru RSUP Persahabatan. J. Respir. Indo 30(2):92-103.

Njalson, R and Norgen, S. 2005. Physiological and Pathological Aspects of Glutatione Metabolism. Acta Paediatr. 94(2):132-137.

Notoatmodjo, S. 2008. Ilmu Kesehatan Masyarakat. PT. Rinneka Cipta. Jakarta.

Nwanjo HU and GO Oze. 2007. Oxidative Imbalance and Non-Enzymic Antioxidant Status in Pulmonary Tuberculosis Infected Subjects: Carcinogenic Potential. Pakistan Journal of Nutrition 6 (6): 590-592

Oja SS, Janaky R, Varga V, Saranasaari P. 2000. Modulation of glutamate receptor functions by glutathione. Neurochem Int 37:299-306.

Oliveira CP, Stefano JT, Cavaleiro AM, Zanella Fortes MA, Vieira SM, Rodrigues Lima VM, Santos TE, Santos VN, de Azevedo Salgado AL, Parise ER, Ferreira Alves VA, Carrilho 
FJ, Correa-Parchwani D, Singh SP, Digisha P. 2011. Total Antioxidant Status and Lipid Peroxides in patient With Pulmonary Tuberculosis. National Journal of Community Medicine 2( 2):225-228.

Psathakis, K.; Papatheodorou, G.; Plataki, M. 2004. 8-Isoprostane, a marker of oxidative stress, is increased in the expired breath condensate of patients with pulmonary sarcoidosis. Chest 125, 1005-1011. Pieratelli R, Banci L, Eady NAJ, Bodigull J, Jones JN and Moods MCE. 2004. Enzyme-catalyzed mechanissm of isoniazid activation in class I and class II peroxidases. Journal Biology Chemistry 279:39000-39009

Plit, M.L., Theron, A.J., Fickl, H., Van Rensburg, C.E, pendel, S., Anderson, R. 1998. Influence Of Antimicrobial Chemoterapy And Smoking Status On The Plasma Concentration Of Vitamin C, Vitamin E, Beta-Carotene, Acute Phase Reactans, Iron And Lipid Petroxides In Patients With Pulmonary Tuberculosis. Int. J. Tuberc. Lung. Dis. 2:590-596.

Pompella A, Visvikis A, Paolicchi A, De Tata V, Casini AF. 2003. The changing faces of glutathione, a cellular protagonist. Biochem Pharmacol 66:1499-1503.

Poot M, Teubert H, Rabinovitch PS, Kavanagh TJ. 1995. De novo synthesis of glutathione is required for both entry into and progression through the cell cycle. $J$ Cell Physiol. 163:555-560. [PubMed: 7539813]

Rahman, I. 2005. Regulation of Glutathione in Inflamation and Chronic Lung Disease. Mutation Research and Molecular Mechanism of Mutagenesis 579:1-2:58-80.

Rahman I, MacNee W. 2000. Oxidative stress and regulation of glutathione in lung inflammation. Eur. Respir.J;16(3):534-554.

Reddy, Y.N., Murthy, S.V., Krishna, D.R, and MC Prabhakar. 2004. Role of Free Radicals And Antioxidants in Tuberculosis Patients. Indian J. Tuberc. 51:213-218.

Sekhar, R.V., Sanjeet, G.P., Anuradha, P., Marvin, R., Ashok, B., George E.T and Farook, J. 2011. Deficient Synthesis of Glutathione Underlies Oxidative 79 Stress in Aging and can be Corrected by Dietary Cysteine and Glycine Supplementation. Am. J. Clin. Nutr. 94:847-853.

Singh, RA., Deepak A., Singh, R. 2010. Oxidative Stress and Ascorbic Acid Levels ini Cavitary Pulmonary Tuberculosis. Journal of Clinical and Diagnostic Research 4: 3437-3441.

Sugiyanta. 2008. Peran glutation sebagai master antioksidan. Biomedis;1(1):48-53.

Suresh, D.R., Vamseedhar, A., Krishneppa, P. and Hamsaveena. 2010. Immunological Correlation of Oxidative Stress Markers in Tuberculosis Patiens. Int. J. Biol. Med. Res:1(4):185-187.

Sutrisna, B. 2002.Permasalah TB paru di Indonesia : Aspek Epidemiologi. Taha, D.A, and Imad, A.J.T. 2010. Antioxidant status, C-Reactive Protein and Status in Patient with Pulmonary tuberculosis. SQU MED.J. 10 (3):361- 369.

Townsend, D. M., Tew, K. D., and Tapiero, H. 2003. The importance of glutathione in human disease. Biomedicine and Pharmacother. 57, 145- 155 
Voskuil MI, Iona L. Bartek, Kevin V and Gary KS. 2011. The response of Mycobacterium tuberculosis to reactive oxygen and nitrogen species. Frontier in Microbiology 2(105):112

Walters DM, Cho HY, Kleeberger SR. 2008. Oxidative stress and antioxidants in the pathogenesis of pulmonary fibrosis: a potential role for Nrf2. Antioxid Redox Signal 10:321-332.

Walubo, A., Smith, P.J, and Folb, P.I. 1995. Oxidative stress during antituberculous therapy in young end elcerly patients.

Wu G, Fang YZ, Yang S, Lupton JR, Turner ND. 2004. Glutathione metabolism and its implications for health. J. Nutr;134(3):489-492.

World Health Organization 2010. Global Tuberculosis Programme : Global Tuberculosis Control. WHO Report.

World Health Organization. 2014. Global Tuberculosis Control 2014. Geneva.

Young, IS. 2005. Oxidative Stress and Vascular Disease : Insight from Isoprostane Measurment. Clin Chem 51(1):14-15.

Yunanto, A., Bambang, S. dan Eko, S. 2009. Kapita Selekta Biokimia : Peran Radikal Bebas pada Intoksikasi dan Patobiologi Penyakit. Penerbit Pustaka Banua: Banjarmasin. p: 243249.

Yuniastuti, A dan Dewi M. 2012. Pengembangan Biomarker Enzimatis Untuk Deteksi Cekaman Oksidatif akibat Paparan Obat Anti Tuberkulosis Pada Infeksi Mycobacterium tuberculosis. Laporan Penelitian. Lembaga Penelitian dan Pengabdian Kepada Masyarakat. Universitas Negeri Semarang. In Press. 84

Zhang H, Forman HJ and Choi J. 2005. $\gamma$-glutamyltrnas peptidase in glutathione biosynthesis. Methods in Enzymology 401:468-483. 